\title{
A JUSTIÇA EM PERNAMBUCO DO OITOCENTOS: OS CRIMES CONTRA A SEGURANÇA DA HONRA (1831-1850)
}

\section{JUSTICE IN PERNAMBUCO OF THE EIGHTEENTH: THE CRIMES AGAINST THE SAFETY OF HONOR (1831-1850)}

\section{Mônica Maria de Pádua Souto da Cunha* Jones Figueiredo Alves ${ }^{*}$}

Resumo: Em 1830 foi publicado o Código Criminal do Império, que seria o primeiro código genuinamente brasileiro. Ele trouxe, juntamente com o Código do Processo Criminal de 1832, regras para regular o julgamento de crimes no Brasil depois da Independência. A estrutura e a organização disposta nessas normas foram reformadas em 1841, com a Lei oㅡ 261, que foi logo regulamentada em 1842. Tudo isso fazia parte de um contexto social vivido no Brasil da primeira metade do Oitocentos. Este artigo tem o objetivo de contribuir para o entendimento sobre a história da Justiça Criminal em Pernambuco, de 1831 a 1850, percurso temporal em que ocorreram diversas estruturações no Judiciário. Admite-se que, para que o estudo seja realizado, é imprescindível conhecer como era realizada a prestação jurisdicional, o que foi possibilitado pela análise de processos judiciais. Este texto traz, por meio da análise dos processos criminais dos crimes de estupro, rapto, calúnia e injúria, um fragmento de como era executada a Justiça no selecionado período, bem como quem eram os acusados, naquele contexto social.

Palavras-chave: Justiça. Pernambuco. História Social do Direito. Direito Criminal.

Abstract: The Criminal Code of the Empire, which would come to be the first genuinely Brazilian code, was published in 1830. Along with the Code of Criminal Procedure from 1832, it brought rules to regulate prosecutions in Brazil after its Independence. The structure and organization set out in these norms were reformed in 1841, with Law $n$. 261 , which was soon regulated in 1842. This was all part of the social context in Brazil in the first half of the 1800s. This article aims to contribute to the understanding of the history of Criminal Justice in Pernambuco, from 1831 to 1850, a time period in which occurred several changes of structures in the Judiciary. It is admitted that, for the study to be carried out, it is essential to know how the jurisdictional provision was carried out, which was made possible by the analysis of legal proceedings. This text brings, through the analysis of the criminal processes of the crimes of rape, kidnapping,

\footnotetext{
"Doutora em História pela Universidade Federal de Pernambuco (UFPE). Mestre em Ciência da Informação pela Universidade Federal de Pernambuco (UFPE). Pós-Graduação em Arquivo pela Universidade Federal de Pernambuco (UFPE). Pós-Graduação em Direito Civil e Processual Civil Centro Universitário Maurício de Nassau de Recife (UNINASSAU). Graduada em História pela Universidade Federal de Pernambuco (UFPE). Graduada em Direito pela Associação de Ensino Superior de Olinda (AESO). Analista Judiciário no Tribunal de Justiça do Estado de Pernambuco (TJPE). E-mail: monica.paduasc@gmail.com.

* Mestrado em Ciências Jurídicas pela Faculdade de Direito da Universidade de Lisboa (FDUL). Graduado em Direito pela Universidade Federal de Pernambuco (UFPE). Graduado em Comunicações Sociais pela Universidade Católica de Pernambuco (UNICAP). Desembargador Decano do Tribunal de Justiça de Pernambuco (TJPE). E-mail: jonesfig@uol.com.br.
} 
slander and injury, a fragment of how Justice was carried out in the selected period, as well as who were the accused, in that social context.

Keywords: Justice. Pernambuco. Social History of Law. Criminal Law.

Recebido em: 01/08/2020

Aceito em: 09/09/2020 


\section{INTRODUÇÃO}

A história humana pode ter seu conhecimento também pela crônica de crimes. A própria genealogia da humanidade conduz-nos ao homicídio de Caim, quando exterminando ("hominis excidium") seu irmão Abel, associa-se ao pecado original cometido pelos pais, o primeiro casal, e nessa gênese de violência, escreve a inferência do mal ao cometimento dos delitos. Todas as simbologias da violência têm essa fonte estrutural. A história futura, desde então, será a relação entre o bem e mal, a vida e a morte, a ordem (lei) e a desordem (infração). O desprezo do bem, da vida e da ordem, é simétrico aos crimes nas suas especificidades e motivações.

Descrever a história dos processos criminais, a seu turno, com a ótica atenta aos códigos e aos costumes dominantes, é uma tarefa que interessa ao historiador para uma compreensão sistêmica dos delitos. As visões legais, socioantropológicas e culturais de época aprofundam a leitura desses processos, servindo o transporte do tempo a vivenciar as realidades neles subjacentes.

Com vistas a contribuir para a formação do entendimento sobre a história da Justiça criminal de Pernambuco de segunda instância, no Oitocentos, este artigo oferece informações sobre a prestação jurisdicional da época. Para isso, foi selecionado um período cronológico que representa a primeira fase do funcionamento do Judiciário na vigência da legislação produzida na época imperial do Brasil, ou seja, de 1831 a 1850, considerada esta última data como recorte temporal por ter sido o momento em que houve a divisão da Justiça em entrâncias. Destaque-se que a pesquisa se limitou à Justiça criminal como recorte temático, considerando que as normas brasileiras dessa área foram as primeiras a serem organizadas em códigos, tornando possível, assim, analisar a nova proposta de regulação dos comportamentos naquele tempo.

Para o período cronológico estudado, foram analisados os processos enquadrados entre os crimes contra a segurança da honra encaminhados ao Tribunal da Relação de Pernambuco. Para o grau de recurso somente havia processos disponíveis para pesquisa referentes aos delitos de estupro, rapto, calúnia e injúria.

Considera-se que esses tipos penais englobam uma área que se destaca para o estudo, pois, na medida em que os casos foram levados para o julgamento do Judiciário, representam consequências de embates do cotidiano das pessoas em seu 
contexto social, e que podem ser usados para ampliar o entendimento sobre o dia a dia da sociedade Oitocentista.

Além de procurar auxiliar na compreensão de um dos aspectos da história do Tribunal da Relação de Pernambuco, o trabalho procura fornecer subsídios para que se entenda quem eram os acusados diante da Justiça de segunda instância daquela província, relacionando as condenações e absolvições com cada perfil social. As fontes primárias utilizadas foram oito processos judiciais encaminhados à Relação de Pernambuco, sob a guarda do Instituto Arqueológico, Histórico e Geográfico Pernambucano (IAHGP).

\section{BREVE PANORAMA DA JUSTIÇA CRIMINAL NO INÍCIO DO PERÍODO IMPERIAL}

O presente estudo remete o tempo à vigência do Código Criminal do Império (BRASIL, 1830a), que sancionado em 16 de dezembro de 1830, constituiu-se em um consagrado diploma penal em sua época. Ele influenciou outros Códigos, a exemplo do Código Penal da Espanha (1848) e outros, na América Latina. Prevista a sua criação pela Constituição Imperial de 1824 (BRASIL, 1824), ainda eram impostas no novo estatuto penal, a pena de galés e a de morte.

Foi no agitado período de sua vigência que penalistas brasileiros, à luz do novo Código, colocaram em discussão a doutrina penal, dentre eles, Braz Florentino, Carlos Perdigão, Tomás Alves Júnior e Tobias Barreto.

Nesse mesmo tempo, anota-se, ainda:

a) a criação do Supremo Tribunal de Justiça, pela Lei de 18 de setembro de 1828 (BRASIL, 1828a), integrado por dezessete Juízes, oriundos das Relações, "por suas antiguidades" e/ou aproveitados ministros de tribunais, extintos;

b) o texto precursor de organização judiciária, sob o advento da Constituição Imperial de 28 de março de 1824, que se apresenta com a lei de 15 de outubro de 1827, onde figuravam os juízes de paz em cada uma das freguesias.

Bem de ver, ademais, que somente com o advento do Código Criminal do Império (BRASIL, 1822), a instituição do Júri, criada pela Lei de 18 de junho de 1822, com a sua competência restrita aos delitos de imprensa, disciplinada pela lei de 20 de setembro de 1830 (BRASIL, 1830b), veio, então, sob a égide da Constituição Imperial (artigos 151 e 152), ampliar sua competência ao crime. 
Acerca do Código Criminal do Império como um texto inovador, incursionando teorias penais, sublinham-se os destaques elencados pelo jurista Roberto Lyra (19021982), em sua obra "Introdução ao Estudo do Direito Criminal". (LYRA, 1946).

Dentre eles, situam-se: “i) no esboço da indeterminação relativa e de individualização da pena, contemplando, já os motivos do crime (...); (ii) na fórmula da cumplicidade (codelinquência como agravante), com traços do que viria a ser a teoria positiva a respeito; (iii) na previsão da circunstância atenuante da menoridade, desconhecida, até, então, das legislações francesa, napolitana e adotada muito tempo após; (iv) no arbítrio judicial no julgamento de menores de 14 anos; (v) na responsabilidade sucessiva nos crimes por meio da imprensa (...); (vi) na indenização do dano ex-delicto como instituto de direito púbico, também antevisão positivista; (vii) na imprescritibilidade da condenação”. (LYRA, 1946, p. 89).

\section{A ORGANIZAÇÃO DA JUSTIÇA EM PERNAMBUCO NO SÉCULO XIX}

Desde 1822, o Judiciário funcionava, em Pernambuco, administrado na segunda instância pelo Tribunal da Relação. Anteriormente os recursos iam para julgamento à Bahia, onde foi instalada a primeira Relação do país.

Antes da criação da Mesa de Desembargo do Paço no Brasil, órgão superior da administração judiciária, estabelecido pelo Alvará de 22 de abril de 1808 (BRASIL, 1808), atuavam como instância recursal na América portuguesa as Relações da Bahia e do Rio de Janeiro, com suas próprias Mesas de Desembargo. No período colonial, se houvesse recurso das decisões dos juízes de fora ou ouvidores na primeira instância, ele seria encaminhado para as Relações e depois poderiam subir para a metrópole, sendo julgados pela Casa de Suplicação de Lisboa e, em casos excepcionais, ao Desembargo do Paço. (WEHLING, 1986).

O Tribunal da Relação de Pernambuco foi criado em 6 de fevereiro de 1821 e instalado em 13 de agosto de 1822, sendo o quarto do país.

Até a publicação do Código do Processo Criminal de 1832 (BRASIL, 1832) e do Regulamento das Relações em 1833 (BRASIL, 1833), ainda estavam presentes na rotina criminal do Judiciário, criado pela Carta de 1824, órgãos, magistrados, outros empregados e muitos procedimentos ainda próprios do período colonial. Nesse momento, não havia ainda nova normatização que regulasse as práticas da Justiça. 
Conviviam juízes de paz, magistrados eleitos, crias do Império, com juízes de fora e ouvidores.

Em 9 de novembro de $1830^{1}$ foi publicado Decreto (BRASIL, 1830c) que regulamentava os procedimentos das Relações. Ele determinava que os processos criminais deveriam seguir as formalidades ditadas pela Carta de Lei de 24 de setembro de 1828, que sancionou a Lei de 23 de setembro de 1828. (BRASIL, 1828b).

Em 1833², cinco anos depois da publicação da Carta de Lei de 23 de setembro de 1828, entrou em vigor o Regulamento das Relações. Ele determinava que cada tribunal seria composto por 14 (quatorze) desembargadores, com um deles nomeado presidente e outro promotor da justiça e procurador da Coroa, soberania e fazenda. $O$ Tribunal da Relação de Pernambuco começou a funcionar com cinco desembargadores, em agosto de 1822, no período da Regência de D. Pedro I.

Com a edição de novas normas, inclusive a Constituição outorgada de 1824, passaram a existir vários órgãos e cargos na Justiça. O Código do Processo Criminal de 1832 configurou o Judiciário de modo que prevaleciam juízes eleitos localmente (juízes de paz) e jurados por sorteio (Júri). Dorlhnikoff (2017) comenta que, inspirado nos códigos napoleônicos, parte do grupo político formado pelos liberais moderados no Brasil queria reformas que trouxessem como modelo principal um Judiciário em que dominassem os magistrados de carreira, com formação em Direito e nomeação pelo governo central.

Os juízes de paz conviviam, durante um período de tempo, desde a regulamentação da sua função, em 1827, por lei específica, com os magistrados do período colonial, mas somente encaminhando queixas, autos de vistoria e fazendo conciliação. Eles começaram a ter uma maior participação na Justiça Criminal depois da publicação do Código do Processo Criminal de 1832.

O Tribunal de Júri era presidido pelos juízes de direito. Esses magistrados também tinham a competência de julgar as causas privativas de empregados públicos não privilegiados, no caso de crimes de responsabilidade. Foram introduzidos como novidade ainda os juízes municipais, que tinham jurisdição criminal e cível. Normalmente atuavam também como juízes de órfãos, especialmente a partir da década de 1840. (GAMA, 1848).

\footnotetext{
1 Já nesse Decreto de 9 de novembro de 1830 e no Regulamento das Relações de 1833 (Decreto de 3 de janeiro de 1833) não se falava mais em chanceler, mas sim em presidente da Relação.

2 Decreto de 3 de janeiro de 1833.
} 
Em 1841, houve uma grande reforma do Judiciário. Na área criminal, uma autoridade que já existia no período anterior (década de 1830), passa a ter maior relevância no âmbito judicial, era o chefe de polícia. Ele poderia ser um juiz de direito ou um desembargador e atuava conjuntamente com os delegados e subdelegados. $A$ estes dois últimos a nova lei atribuiu mais poderes. Eles tinham a função de preparar os processos criminais e de julgar alguns delitos policiais, limitada a sua jurisdição aos distritos de sua designação. Cada termo tinha um delegado de polícia e cada freguesia um subdelegado. Nas freguesias atuavam os juízes de paz, magistrados eleitos que tinham a competência de conciliar as partes, antes das demandas, e de conhecer definitivamente todas as causas até o limite de $16 \$ 000$ réis, também presidindo os atos preparatórios às eleições. (GAMA, 1848).

$\mathrm{Na}$ malha da Justiça criminal ainda eram encontrados outros empregados que a faziam funcionar. Existiam os inspetores de quarteirão, que agiam como agentes de polícia, e os integrantes do Júri que, depois da reestruturação da Justiça de 1841, reuniam-se nas cabeças dos distritos e, como exceção, em alguns municípios especialmente desprovidos dessa qualificação (GAMA, 1848). Pode-se citar também os escrivães, que acompanhavam todos os magistrados em seus julgamentos e não recebiam ordenado dos cofres gerais ou provinciais, somente os emolumentos pagos pelas partes. (MELLO, 1979).

Sobre a organização judiciária de Pernambuco pode-se dizer que, em 1808, contava com as ouvidorias de Pernambuco, Itamaracá, Alagoas, Paraíba do Norte e com a de Jacobina, na parte pertencente àquela província, pois, nessa época ainda repartia com a Bahia esse território. (MELLO, 1979).

O Alvará de 15 de janeiro de 1810 (BRASIL, 1810) criou a comarca do Sertão de Pernambuco, com jurisdição na Vila de Cimbres (Pesqueira), Garanhuns, Flores, Tacaratu, Cabrobó, 2ª vila da Barra, a povoação de Pilão-arcado, desligada da antiga comarca de Pernambuco, e as povoações de Campo Largo e Carunhanha, desligadas da comarca de Jacobina, na Bahia. (MELLO, 1979).

Em resumo, Pernambuco, nas primeiras décadas de 1800, no que diz respeito à Justiça, era composta pelas comarcas de Alagoas, Pernambuco e do Sertão de Pernambuco e Goiana, que ainda nesse tempo era sujeita à correição da Ouvidoria da Paraíba. A Ouvidoria de Pernambuco tinha jurisdição na cidade de Olinda e nas vilas do Recife, Igarassu, Serinhaém, Cabo, Santo Antão, Paudalho e Limoeiro. (MELLO, 1979). 
Em 1814, o governador de Pernambuco propôs a divisão da Ouvidoria em duas comarcas, que seriam Olinda e Recife, sendo Olinda a cabeça de comarca, composta pelos termos da cidade de Olinda e das vilas de Igarassu, Paudalho, Limoeiro e Goiana ${ }^{3}$. A comarca do Recife seria formada pelos termos do Recife, Santo Antão, Cabo e Serinhaém. Em 1815, o alvará de 30 de maio criou a nova comarca de Olinda, a partir dessa requisição do governador. (MELLO, 1979).

Confirmando a assertiva de que a estrutura judicial do período colonial foi mantida pelo menos até a publicação do Código do Processo Criminal no final de 1832, no início do Império os juízos de fora do Recife e de Goiana permaneceram funcionando segundo as normas anteriores. Mesmo diante das mudanças anunciadas pela Constituição outorgada de 1824 para a Justiça e da legislação extravagante editada, somente aquele Código do Processo Criminal autorizava os presidentes, em conselho, a dividir as províncias em novas comarcas. Assim, em 20 de maio de 1833 Pernambuco foi dividido em 9 comarcas: Recife, Goiana, Nazaré, Limoeiro, Santo Antão, Rio Formoso, Bonito, Brejo e Flores. Logo depois, foram criadas mais quatro comarcas: Garanhuns (Lei de 6 de junho 1836), Boa Vista (Lei de 19 de abril 1838), Paudalho e Cabo (Lei de 5 de maio de 1840). A comarca de Bonito foi extinta em 19 de abril de 1838 e restabelecida em 5 de maio de 1840. (MELLO, 1979).

Mais tarde, em 1842, depois da reforma da Justiça de 1841 Pernambuco contava com 13 comarcas: Recife, Cabo, Rio Formoso, Santo Antão, Bonito, Limoeiro, Nazaré, Paudalho, Goiana, Brejo, Garanhuns e Boa Vista (GAMA, 1848). Nessa data, Recife já era cabeça de comarca da província de Pernambuco. A comarca do Recife era formada pela cidade do Recife, ilha de Fernando de Noronha e os municípios de Olinda e Igarassu, a este último também compreendendo a ilha de Itamaracá. (GAMA, 1848).

\section{CONTEXTO CRIMINAL EM PERNAMBUCO: OS CRIMES CONTRA A SEGURANÇA DA HONRA}

Quem eram os sujeitos potencialmente perigosos em Pernambuco na primeira metade do Oitocentos, no que diz respeito ao que estava legalmente estabelecido? A resposta a essa questão inicia-se pela compreensão sobre a qualidade e a quantidade

\footnotetext{
3 "[...] a capitania da Paraíba já estava separada e independente, e a de Itamaracá estava incluída em Pernambuco, e nenhuma razão podia haver para que Goiana ficasse pertencendo à comarca de governo diverso". (MELLO, 1979, p. 115).
} 
de indivíduos que ocupavam o espaço geopolítico da província no século XIX. Acontece que as informações sobre a demografia pernambucana, antes de 1872, ano em que houve o primeiro recenseamento oficial no Brasil, são imprecisas. Essa situação não é um privilégio de Pernambuco. Katia Mattoso (1992) enfrentou o mesmo obstáculo ao analisar a população da Bahia, de 1780 e 1890, como muitos outros autores. É tanto que Moura Filho (2005, p. 15), em sua dissertação sobre as estatísticas demográficas no Oitocentos, comenta que "[...] entre a independência e a realização do recenseamento geral de 1872, a produção sistemática de estatísticas populacionais amargou um longo recesso no Brasil".

Para iniciar os estudos sobre o perfil dos acusados de crime pela Justiça pernambucana, especialmente daqueles originados das comarcas de Pernambuco, consta do conteúdo apresentado, para fins de conhecimento geral sobre a população local e comparação com os números apresentados sobre os acusados na Justiça, a quantidade de habitantes em relação ao território como um todo, na primeira metade do século XIX e, em especial, do município do Recife, capital da província.

A partir da constatação de que as informações disponíveis sobre a população de Pernambuco no Oitocentos são incompletas para o período cronológico em estudo, pode-se dizer que as fontes existentes sobre a matéria somente permitem que se tenha uma ideia de ordens de grandeza quanto à quantidade de habitantes, dificultando o entendimento acerca da dinâmica interna daquela sociedade, que se sabe era formada por indivíduos com características diversas, sejam elas sociais, políticas, ideológicas, psicológicas ou econômicas, tal qual disse Kátia Mattoso (1992) para a Bahia.

Entre os autores que trouxeram informações sobre a população de Pernambuco no século XIX, um dos mais usados como referência acerca a matéria e da administração da Justiça no Oitocentos é Mello (1979). Apesar do levantamento por ele apresentado e outros trabalhos sobre Pernambuco durante o século XIX não serem suficientemente abrangentes e sistemáticos, a ponto de trazerem números totalmente confiáveis (MOURA FILHO, 2005), a publicação de Mello sobre o assunto tem sido bastante utilizada, provavelmente pela raridade de títulos compilados sobre esse quesito, como também pela razão de que o autor indica as fontes consultadas. Ressalte-se que muitas dessas fontes usadas por Mello (1979) não mais existem para serem conferidas, restando aos pesquisadores confiar na obra do autor. Por esses motivos, para este artigo foi usada a publicação de Mello (1979) como fonte principal, 
no que concerne às estimativas sobre o quantitativo de habitantes em Pernambuco no século XIX, como também no que diz respeito às informações referentes à Justiça.

Segundo Mello (1979), em 1810, Pernambuco contava com uma população de aproximadamente 274.687 habitantes, excluída a comarca de Alagoas que, naquela época, pertencia à Bahia. Em 1815 esse número subiu para 339.778 e, doze anos depois, em 1827, já chegava a 450 mil habitantes. O autor fez um cálculo para a província no final da década de 1830, estimando em 620 mil o número de habitantes no local.

Nos mapas apresentados por Mello (1979, p. 310-321) sobre a população de Pernambuco, seus municípios e comarcas, ele classificou os indivíduos pelo sexo e depois pelo estatuto jurídico, se ingênuo/livre, liberto ou cativo/escravo e, em alguns dos quadros, até os estrangeiros, não atribuindo a estes últimos a cor, somente o sexo.

Conforme classificação de Mello (1979) para livres pobres, pode-se dizer que, em 1827, existiam em Pernambuco 1.796 mendigos ou pobres de porta, dos quais 850 eram do sexo masculino e 946 do sexo feminino. Em 1840 essa situação não mudou muito. Existiam 1.715 pobres, contando com 737 do sexo masculino e 978 do sexo feminino. (MELLO, 1979).

Mello (1979, p. 307) apresentou um quadro de profissões para os habitantes de Pernambuco, que denominou de liberais e industriais, enumerando-as da seguinte maneira: a) Membros do clero secular; b) Proprietários de prédios urbanos; c) Empregados públicos pagos pelo Estado; d) Ditos pagos pelas câmaras; e) Desembargadores, juízes de direito e municipais; f) Juízes de paz; g) Delegados e subdelegados de polícia; h) Inspetores de quarteirão; i) Advogados; j) Escrivães de todas as classes; k) Professores públicos; I) Ditos particulares; m) Estudantes de todas as classes das aulas públicas; n) Médicos e cirurgiões; o) Boticários; p) Oficiais mecânicos; q) Escravos nas cidades e vilas; r) Ditos nos campos.

Destaque se dê à classificação criada por Vellasco (2004, p. 78) para as ocupações dos indivíduos que viviam no Brasil na primeira metade do Oitocentos. O autor decidiu-se por definir alguns critérios classificatórios, que foram aproveitados para este trabalho. Foram eles: a) Elites locais: por indicação de ocupação, títulos, cargos, patentes que conferiam renda, status e/ou prestígio social, negociantes de porte, grandes e médios proprietários rurais, fazendeiros e lavradores; b) camadas médias: funcionários públicos de menor escalão, profissionais liberais (professores, 
boticários, etc.), oficiais mecânicos, militares de baixa patente, pequenos comerciantes (presumidos), artesãos, produtores rurais independentes, pequenos lavradores; c) livres pobres: assalariados sem profissão específica, irregulares ou de ocupação incerta, jornaleiros, roceiros e agenciadores, agregados, capitães do mato, serviços domésticos, lavadeiras, etc.; d) escravos.

Apesar da proposta deste trabalho não se tratar de construir nova classificação para a hierarquia da sociedade pernambucana no século XIX, mas sim indicar um perfil daqueles acusados de crimes contra a segurança da honra entre 1831 a 1850, que recorreram à Relação, ao mesmo tempo que se aproveitou a classificação de Vellasco (2004), seguiu-se a linha apontada por Katia Mattoso (1973) para conhecer a estrutura social daquela província, tentando captar a realidade do homem comum, com todas os problemas de seu cotidiano, a partir dos relatos apanhados nos processos judiciais criminais. Aproveitando o conhecimento sobre a conjuntura e a estrutura social e política de Pernambuco, considerou-se, assim, o grupo social que esse "homem médio" representava a partir de sua ocupação, seu modo de vida, seu grau de instrução, sua idade, sua origem geográfica, levando em conta todas as identificações apresentadas no processo judicial criminal, inserindo-o na classificação adaptada àquela criada por Vellasco (2004).

Como nos processos criminais as ocupações eram identificadas de forma mais específica, inclusive no concernente às profissões/ocupações particulares e públicas, optou-se, para esta pesquisa, por usar a indicação que se encontra nos documentos judiciais, considerando-se que retrataria mais de perto a realidade local para o fim de analisar o perfil dos acusados.

Quanto à cor, Mello (1979) apresentou a seguinte identificação para os habitantes da província de Pernambuco: brancos, índios, pardos e pretos. Esta última subdividiu em crioulos e d'África. Essa forma de identificação do autor se aproximada muito do que foi encontrado na maioria dos casos nos processos judiciais criminais de Pernambuco

Sobre a massa de acusados dessa nova Justiça que se impunha nas primeiras décadas do século XIX, escreveu Vellasco (2004) que, por muito tempo, o estudo sobre a sociedade brasileira foi realizado com base na polaridade senhores/escravos como sendo a única vertente importante a ser observada, visão atrelada a análises predominantemente econômicas da sociedade. Katia Mattoso (1992, p. 579) comentou também que essa visão, "a mais pobre" de todas, que 
desconsidera a mobilidade e a evolução das hierarquias sociais no Brasil do período colonial até a industrialização moderna, é ainda imprecisa, deixando de lado as diversidades existentes no país, que conta com um imenso território e com evoluções regionais diferenciadas. Uma parte dessa massa de acusados é que foi analisada neste artigo.

\subsection{Estupro (artigos 219 a 225)}

O tema do estupro sempre desafiou diversas escolas do pensamento. Do simbolismo mitológico ou clássico às escolas do Direito, da Criminologia ou da Antropologia Criminal; e das escolas de Filosofia, da Sociologia ou da Psicanálise, o estupro aparece nos escritos de todos os tempos. Mesmo um reduzido número de textos do século IX o retratam como "onipresente", segundo relata o historiador George Duby (1981), adiantando que o arcebispo de Rheims, Hincmar, no início da Idade Média produziu uma obra a respeito 4 .

Não há uma obra clássica acerca da história do estupro, no Brasil, em suas dimensões socioculturais, dentro das sociedades antigas ou mais recentes, sob o tratamento dos costumes e da lei. Todavia, tem ele, inegavelmente, diversas naturezas, inclusive a política, em função da manutenção do poder; como denunciava Maquiavel (1982), em capítulo de seus "Discursos", no século XVI, por representar um "perigo político".

Apesar disso, existem coletâneas que se destacaram a respeito, uma delas "Rape", organizada por Sylvana Tomaseli e Roy Porter (1989), pesquisadores e historiadores ingleses. A sua edição brasileira, Tomaseli e Porter (1992) com tradução de Alves Calado, intitulada "Estupro" (273 p.) foi lançada em 1992, pela Rio Fundo Editora (RJ).

A violação do corpo representa uma tragédia social, que constitui, na essência, a submissão da mulher, defrontada em sua histórica luta de emancipação, por autonomia da pessoa e de sua dignidade. A vitimização sexual da mulher atravessa uma crônica de horrores, a exemplo de estupros coletivos e dos jogos dominantes de conveniência masculina. Os abusos sexuais procuraram ser desvendados por Sigmund Freud (1968), em sua teoria da sedução, enquanto uma literatura criminalista trabalha a complexidade das teorias no tema. Induvidosamente,

\footnotetext{
4 "De la Répression du Rapt".
} 
a sedução, até recentemente tratada em nossos códigos como tipo penal, difere do crime de estupro.

A ciência social também busca compreender o estupro, em suas mais diversas configurações, desde a antiguidade. Amor e ódio, doença ou dominação, são elementos que nele visualizam o fato histórico ou o fato jurídico, penalmente relevante. O estupro, em Lucrécia ou no rapto das Sabinas, tem suas devidas representações clássicas e permanece, no tecido social da história de cada época, com significações precisas. Sempre foi um crime gravíssimo, repudiado pelo senso moral.

Para que se condenasse um acusado de estupro, no Código Criminal de 1830, seria necessário não somente que ele tivesse praticado um dos verbos do tipo citados no Diploma Legal, como deflorar ou ter cópula carnal com mulher. Existiam outras exigências legais para o crime se configurar.

A primeira conduta descrita pelo Código de 1830 como estupro era deflorar mulher virgem que fosse menor de 17 anos. Para comprovar essas duas situações, que a vítima era virgem e o limite da idade, a mulher deveria se submeter a um exame de corpo de delito e provar ter menos de 17 anos, por meio de algum documento, já que muitas mulheres, pelo menos na primeira metade no século XIX, especialmente aquelas das camadas mais pobres, sequer sabiam quantos anos tinham ao certo. Quando muito, tinham conhecimento sobre a igreja na qual haviam sido batizadas. Essa falta de informação beneficiava os réus que, além de usarem do artifício de afirmar que a ofendida não era menor de 17 anos, ainda argumentavam que a vítima do estupro não era "honesta", ou seja, que já não era mais virgem quando o ato foi consumado e isso, se provado fosse, poderia inocentar o acusado de ter praticado o crime do artigo 219.

Durante a apuração do delito, o juiz de direito teria que formular perguntas para que o réu, acusado de estupro, respondesse. Tinoco (2003) entendia que, para que o magistrado cumprisse com as formalidades exigidas pelo Código do Processo Criminal de 1832, deveria perguntar se o réu, no dia e lugar específico, deflorou a vítima, que era mulher virgem; se a ofendida era menor de 17 anos e se ele procedeu empregando violência ou ameaças contra ela. Tudo isso para conseguir identificar ou não os elementos do tipo penal presentes no artigo 219.

Saber se houve violência ou ameaça, segundo o autor supracitado, significaria identificar se houve consentimento da vítima para o ato. Se o réu não tivesse agido com violência ou ameaça, estaria absolvido das penas do artigo 219, podendo ser 
acusado na forma do artigo 222, com o agravante da circunstância do defloramento, como dispunha o artigo 17 do mesmo Código Criminal de $1830^{5}$.

As penas para os condenados no artigo 219 variavam. Não havia prisão, somente desterro de até 8 meses a 3 anos, para fora da comarca em que residisse a deflorada, e ainda teria a obrigação de dotá-la.

O artigo 220 trazia penas maiores para o réu condenado, aumentando o tempo de desterro para, no máximo, seis anos. Os incursos nesse artigo seriam aqueles que cometessem estupro em mulher que estivesse sob a sua própria guarda. E o artigo 221 acrescentava que, se fosse o acusado parente da vítima, poderia ser punido com até seis anos de desterro e teria também que dotar a ofendida, e mais, seria negado a ele o direito à dispensa da pena pelo casamento.

Para esses dois últimos casos, Tinoco (2003) sugeria que fossem acrescentadas algumas outras questões no interrogatório. Para o artigo 220, se o réu tinha em seu poder (ou guarda) a deflorada; no caso do artigo 221, se o réu era pai (padrasto, irmão ou outro parente) da deflorada.

O artigo 222 trazia outra conduta que era punida como estupro. Um homem que tivesse cópula carnal, por meio de violência ou ameaça, com mulher honesta, praticava o crime de estupro e teria como pena até 12 anos de prisão simples e ainda teria que dotar a ofendida. Também para esse caso Tinoco (2003) considerava que o juiz de direito deveria fazer algumas perguntas chave para ter condições de obter respostas suficientes para a decisão final. Eram elas: se o réu, no dia e local específico teve, por meio de violência ou ameaça, cópula carnal com a ofendida; se a ofendida era mulher honesta e se ela era prostituta. Quanto à prostituição, se ela fosse confirmada como prática da vítima estuprada, a pena máxima seria de 2 (dois) anos de prisão simples, pois a mulher passava a não ser considerada "honesta", considerando o legislador que a vítima não merecia o mesmo amparo da lei.

Clóvis Beviláqua (1896, p. 98), afirmava que, com base nas estatísticas criminais brasileiras da segunda metade do século XIX, as mulheres nascidas no Brasil eram consideradas "honestas". Nesse caso, o adjetivo "honesta" foi usado no sentido de não praticar crimes. Explica o jurista que, em comparação com a "delituosidade" do sexo masculino, a do sexo feminino estava para $2 \%$ e $3 \%$. Ainda informou o autor que os atos delituosos praticados pelas mulheres, na maioria das

5 Segundo Tinoco (2003), esse entendimento foi formalizado em norma pelo Aviso no 512 de 5 de novembro de 1862. 
vezes, foram relacionados com lesão corporal. Entretanto, para ele, "a válvula por onde se Ihe escapam os maus instintos é a prostituição", enfatizando a mesma intolerância presente no Código Criminal de 1830, quando minimizou a pena quando a vítima de estupro era acusada de prostituição.

Para terminar, restavam os artigos 223 e 224 que estabeleciam penas para o crime de estupro. O primeiro seria aplicado a quem praticasse simples ofensa pessoal para fim libidinoso, causando dor ou algum mal corpóreo à mulher, sem que se verificasse cópula carnal. Para o segundo, estaria incurso aquele que seduzisse mulher honesta menor de 17 anos e tivesse com ela cópula carnal. As penas para aquele que não tivesse cópula carnal seria de, no máximo, seis meses de prisão simples e multa, bem menor do que o que tivesse tido. Se tivesse ocorrido a cópula carnal, a pena seria de até três anos de desterro para fora da comarca em que residisse a ofendida, e ainda teria que dotá-la.

O último artigo que tratava sobre o crime de estupro era o 225. Ele determinava que, se o réu casasse com a vítima, ficaria isento das penas dos artigos 222, 223 e 224. Esse também era o caso dos acusados no artigo 219, conforme citado anteriormente. Tinoco (2003) comentava o conteúdo de uma consulta sobre a aplicação do artigo 225 do Código Criminal de 1830, ao presidente da Relação de Pernambuco, Francisco Balthasar da Silveira, em 20 de novembro de $1862^{6}$.

O Conselheiro da Relação de Pernambuco dizia que o artigo 225 não poderia ser entendido e aplicado isoladamente. Que a sua disposição seria relativa e subordinada à última parte do artigo 219, que se harmonizava com o artigo 228, relacionado ao delito de rapto. Chamava atenção de que haveria muitos perigos e absurdos na sua aplicação isolada. O exemplo que usou para ilustrar as suas assertivas é que foi interessante. Ele indicou os problemas que poderiam ser causados se um "preto" escravo, réu em crime de estupro, optasse por casar-se com a sua vítima, moça livre e branca, de "família honesta" e de "elevada posição", para se livrar das penas de estupro. Dizia que, se isso fosse permitido, "estaria criando perigos e escândalos para o bem-estar e paz das famílias, e no estado de nossa educação, costumes e civilização". Outra situação narrada por ele ocorreria quando o crime fosse perpetrado por fraude ou violência, em que o casamento não seria a melhor solução, pois a ofendida poderia não querer se unir ao criminoso.

6 Como são somente 11 anos após o período cronológico estudado, foi inserida essa informação, considerando que esse entendimento poderia ser frequente nos anos anteriores. 
Detalhe importante para o conselheiro do mesmo caso analisado por Tinoco (2003), era que não bastava, para que o réu se livrasse da culpa, somente a sua afirmação de que queria se casar com a vítima. Seria necessário que o casamento fosse realizado, para que tivesse o benefício de se livrar da pena concedido. E a ofendida deveria declarar que concordava com a união, bem como o seu responsável.

Lembrou ainda o magistrado do processo comentado acima que esse dispositivo sobre o casamento usado para suprir o ato delituoso tinha como fonte a antiga legislação, as Ordenações Filipinas, Livro V, Título 16, § 3ํㅡ, e no Título 23, baseado ainda no Repertório, Tomo 1ํㅡㄹ página 371. Concluiu seus comentários dizendo que devia o juiz de direito dar execução ao Código Criminal, evitando perigos e escândalos, tendo o cuidado de aplicar os artigos de forma harmônica.

O único caso de estupro estudado neste texto, em que o réu foi condenado, foi iniciado pela queixa de Joaquim Aurélio de Carvalho contra Frederico Antônio de Mello, português, que vivia de negócios ${ }^{7}$. O pai da vítima, que interpôs a queixa, informou que a sua filha Lisbina era menor de 16 anos, vivia honestamente em sua casa, e foi seduzida pelo denunciado, que conseguiu ter com ela cópula carnal. O réu foi encontrado às duas horas da manhã, no local onde dormia a dita menor, achandose ela junto ao suplicado, que foi preso pela patrulha e recolhido à cadeia da cidade do Recife. Pediu o queixoso que fosse realizado o corpo de delito.

O acusado, para se defender, disse que Lisbina não era mais virgem e que tinha mais de 17 anos de idade. Questionou a autenticidade da certidão de idade apresentada pelo pai da ofendida, que havia sido fornecida pelo pároco da freguesia do Cabo, local de batismo de Lisbina. Mas o Júri não acatou o pedido do acusado de desconsiderar a certidão, que foi inserida mediante o procedimento de justificação durante o processo.

O Júri terminou condenando o réu, e o juiz confirmou a sentença, obrigandoo à prisão, no grau máximo do artigo 224 do Código Criminal de 1830, que ficou estabelecida em três anos de desterro para fora da comarca em que residia Lisbina e a dotá-la. O réu apelou ao TRPE, que não conheceu da apelação por não se apresentarem as fórmulas do artigo 301 do Código do Processo Criminal de 1832.

Nas outras três situações examinadas neste trabalho, em que houve acusação de estupro, todos os réus ficaram em liberdade. Em um dos autos somente

\footnotetext{
${ }^{7}$ Fonte IAHGP. Tribunal da Relação de Pernambuco. Apelação. Apelante: Frederico Antônio de Mello. Apelado: Joaquim Aurélio de Carvalho. 1839. Cx. 1.
} 
se julgou um Habeas Corpus em que o preso tinha sido acusado de estupro ${ }^{8}$. Ele conseguiu a concessão da ordem, ficando em liberdade para responder à acusação em outro processo. Quanto aos outros dois, foram absolvidos na primeira e segunda instância. Um dos réus era doutor em letras e bacharel em direito Universidade de França, Academia de Paris, acusado de deflorar Henriqueta Augusta Ferreira, de 14 anos de idade 9 . O outro, menor de idade, de 13 para 14 anos (consta assim nos autos), foi acusado pelo pai de Maria das Dores, de 8 anos de idade, de estupro, por ter deflorado a menor ${ }^{10}$.

Sobre a possibilidade de os menores de idade serem réus ou não, o $\S 1^{\circ}$ do artigo 10 do Código Criminal de 1830 dispunha que os menores de 14 anos de idade não seriam julgados criminosos. E o Aviso no 190, de 17 de julho de 1852 (BRASIL, 1852) declarou ao Presidente da Província de São Paulo que essa regra seria também aplicada aos escravos menores, segundo Tinoco (2003), tomando como fundamento os princípios da humanidade, mesmo considerados os termos genéricos do artigo 1ำ da Lei de 10 de junho de 1835 (BRASIL, 1835) ${ }^{11}$.

No crime de estupro, o sujeito ativo teria que ser do sexo masculino. Observou-se pelo menos um caso de um homem da cor "preta" como réu e que, independentemente dessa sua qualidade e, sendo agricultor e pobre, conseguiu a concessão de Habeas Corpus para responder pelo crime em liberdade ${ }^{12}$. Ressalte-se que a vítima do delito era uma "preta", crioula, filha de Manoel Gomes que, como disse o reclamante, foi deflorada "a pretexto de casamento.

Saliente-se o comentário do Conselheiro da Relação de Pernambuco, em resposta a consulta a ele realizada, exposta aqui neste artigo, quando falava dos problemas que poderiam ser causados se um réu de estupro, de cor "preta" e escravo, quisesse usar do benefício de se ver isento da pena e casar com sua vítima, sendo esta branca, livre e de "família honesta e de elevada posição", que concluiu dizendo

\footnotetext{
${ }^{8}$ Fonte IAHGP. Tribunal da Relação de Pernambuco. Recurso. Recorrente: o Juízo. Recorrido: José Pais de Souza. 1844. Cx. 3.

9 Fonte IAHGP. Tribunal da Relação de Pernambuco. Apelação. Apelante: a Justiça. Apelado: Dr. Clemente Falcão de Souza. 1831. Cx. 1.

${ }^{10}$ Fonte IAHGP. Tribunal da Relação de Pernambuco. Apelação. Apelante: a Justiça. Apelado: João Ricardo de Sant'Anna. 1851. Cx. 3.

${ }^{11}$ Art. 1 Serão punidos com a pena de morte os escravos ou escravas, que matarem por qualquer maneira que seja, propinarem veneno, ferirem gravemente ou fizerem outra qualquer grave offensa physica a seu senhor, a sua mulher, a descendentes ou ascendentes, que em sua companhia morarem, a administrador, feitor e ás suas mulheres, que com elles viverem. Se o ferimento, ou offensa physica forem leves, a pena será de açoutes a proporção das circumstancias mais ou menos aggravantes.

12 Fonte IAHGP. Tribunal da Relação de Pernambuco. Recurso. Recorrente: o Juízo. Recorrido: José Pais de Souza. 1844. Cx. 3.
} 
que os dispositivos relacionados ao estupro deveriam ser analisados com cuidado, para que se evitasse "perigos à civilização".

\subsection{Rapto (artigos 226 a 228)}

O rapto aparece como outra figura penal que envolve a honra e atenta contra a liberdade sexual da mulher.

$\mathrm{Na}$ atualidade, a Lei no 11.106, de 28 de março de 2005 (BRASIL, 2005), descriminalizou o crime de rapto, em suas diversas modalidades, tendo a referida lei, ao revogar os artigos 219, 220, 221 e 222 do Código Penal, introduzido o inciso V ao parágrafo $2^{\circ}$ do artigo 148 do $\mathrm{CP}$, como forma qualificadora do crime de sequestro e cárcere privado (art. 148, caput), ou seja, quando o crime for "praticado com fins libidinosos".

Nas origens da história de Roma, aponta-se o rapto das Sabinas como a forma de sua expansão populacional. Plutarco e Tito Lívio descrevem o rapto das jovens sabinas, de famílias vizinhas, pela primeira geração dos romanos que as tomaram para si como esposas, garantindo a continuidade de Roma.

No caso histórico, embora o vocábulo "estupro", seja a tradução latina de "raptio", certo é que no episódio de formação de Roma, o rapto das sabinas não teria empreendido abusos sexuais, conforme escreve Tito Lívio, em contraponto ao delito de estupro, assegurando Rômulo os casamentos legítimos entre eles, com os direitos cívicos e bens materiais

Na hipótese ora em estudo, tem-se também a situação do casamento do raptor com a ofendida. Mas este, em havendo, serviria a elidir a sanção penal em face do crime.

Para se configurar o rapto, no Código Criminal de 1830, seria necessário que o acusado tirasse mulher, com violência, da casa ou lugar em que estivesse, para fim libidinoso (art. 226), ou tirasse mulher menor de 17 anos, virgem, ou reputada como tal da casa de seu pai, tutor ou curador ou de quem estivesse com a sua guarda. As penas para esse delito variavam de 11 anos e 10 meses de prisão com trabalho e a obrigação de dotar a ofendida, ou até 5 meses e 10 dias de prisão, dependendo do grau da pena estabelecida pelo juiz, impostas de acordo com a conduta do acusado, em cada caso específico. O artigo 228 do Código Criminal de 1830 estabelecia que, se houvesse o casamento da ofendida com o acusado, este ficaria isento das sanções. 
O único caso de rapto encontrado no acervo pesquisado, que chegou à Relação de Pernambuco, foi julgado em 1843. Pedro José de Oliveira, de cor branca, morador da cidade do Recife, fez uma denúncia como administrador da menor Francisca $^{13}$. O denunciado se chamava Joaquim Ignácio Guimarães, era português, e estava preso na cadeia da cidade do Recife-PE, por ter raptado Francisca. Conta Pedro, o denunciante, que recolhera, junto com a sua esposa, em sua casa, uma mulher pobre, vinda do interior, de nome Joana. Ela tinha ido à capital para "soltar" um filho recrutado, trazendo em sua companhia sua filha Francisca, que a mãe dizia ter 12 anos de idade, em 1837. A mãe de Francisca terminou morrendo na casa do denunciante e a menor ficou no local, com a função de cuidar de seus filhos, por 4 anos.

Continuava a narrativa, o denunciante, declarando que tudo fez para educar Francisca como mulher honesta e lhe dar estado de casada, nos seus 16 anos de idade completos. Disse que o denunciado, estando de caixeiro na loja de Manoel Ferreira, onde foi despedido por ter sido preso por importunar outras moças "honestas", principiou a seduzir e angariar confiança da menor Francisca, e a raptou da casa do denunciante para "fins libidinosos". E, depois de andar com ela pelas ruas, deixou-a desamparada. Por isso, disse o denunciante, que requereu ao prefeito a prisão do denunciado e o depósito da menor raptada sob sua guarda, e a condenação do denunciado por rapto.

O acusado foi pronunciado pelo juiz e o promotor fez o libelo. O réu se defendeu, contrariando o libelo, afirmando que Francisca não foi raptada e não era virgem. Disse que, sendo o denunciante viúvo e moço, não tinha em casa outra mulher que não fosse a dita raptada, que não era sua parente. Que a dita vítima, em 1840, tinha sido vista grávida na festa de Nossa Senhora do Terço e logo depois se ocultou dos olhos do público, e que era de conhecimento público que teria abortado. $\mathrm{E}$ ainda que ela era maior de 17 anos, pois chegou na cidade em 1835 e já parecia ter passado da puberdade.

O júri não acreditou nas palavras do acusado e o condenou no grau médio do artigo 227 do Código Criminal e em uma indenização, em outubro de 1841. O juiz de direito sentenciou o réu a dois anos de prisão simples e a dotar a ofendida.

13 Fonte IAHGP. Tribunal da Relação de Pernambuco. Apelação. Apelante: Joaquim Ignácio Guimarães. Apelado: Pedro José D’Oliveira. 1842. Cx. 2. 
Inconformado com a sentença, o denunciado apelou à Relação, que julgou improcedente o recurso por não se apresentarem as fórmulas do artigo 301 do Código do Processo Criminal de 1832, em 10 de janeiro de 1843. Ou seja, o resultado foi a confirmação da sentença de condenação do réu.

\subsection{Calúnia e injúria (artigos 229 a 246)}

O patrimônio moral das pessoas sempre se constituiu em um bem jurídico a ser protegido contra as condutas criminosas que tendem a cometer violações à honra.

A detração como fórmula de ofensa, nos dolos específicos dos delitos que a classificam em calúnia, difamação e injúria (artigos 138, 139 e 140 do Código Penal de 1940), tem suas vertentes na imputação falsa a alguém de um fato criminoso, ou de um ato imoral, desonroso, ofensivo à reputação e bom nome, ou na ofensa à dignidade ou o decoro de alguém.

No Código Criminal de 1830, o delito de calúnia se configurava quando o criminoso atribuísse falsamente a alguém um ato que a lei tivesse qualificado como crime. Esse ato teria que ser regido por procedimento oficial de Justiça ou por ação popular, podendo ser cometido por meio de papéis impressos ou qualquer outra forma ${ }^{14}$.

Quanto à injúria, poderia ser condenado o acusado que: imputasse um fato criminoso que não fosse considerado calúnia; imputasse a alguém vícios ou defeitos que pudessem expor a vítima ao ódio ou desprezo público; imputasse vagamente ao ofendido crimes ou vícios sem fatos especificados; prejudicasse a reputação da vítima; ofendesse alguém por meio de discursos, gestos ou sinais considerados insultos diante da opinião pública ${ }^{15}$.

Para falar sobre calúnia e injúria no século XIX é necessário fazer uma retrospectiva das normas que regulavam esses delitos. Para isso, foi selecionada uma decisão do Supremo Tribunal de Justiça que, mesmo sendo da década de 1870, mais de vinte anos depois do período estudado neste trabalho, ela é de grande utilidade, já que trouxe uma análise da evolução do direito criminal acerca dos crimes descritos neste item.

\footnotetext{
${ }^{14}$ Art. 229 e segs. do Código Criminal de 1830.

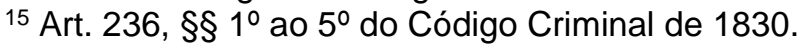


O texto da decisão trouxe também uma discussão sobre a revogação da Lei de 20 de setembro de 1830, anterior da Código Criminal de 1830, que regulamentava somente os delitos de abuso de imprensa, com condutas listadas para os crimes de calúnia e injúria, incluindo o procedimento para apuração e julgamento.

No acórdão, os magistrados do STJ sustentavam que, depois da publicação do Código Criminal de 1830 e, em 1832, do Código do Processo Criminal, a Lei de 20 de setembro de 1830 estaria revogada. Ele se posicionou contrariamente a um outro acórdão de 1848 do próprio Supremo, que foi encaminhado pela Relação de Pernambuco, e já havia sido usado como paradigma sobre a matéria ${ }^{16}$.

A decisão do Tribunal do ano de 1877 dizia que a Lei de 20 de setembro de 1830, considerada especial porque regulamentava somente os crimes relacionados ao abuso da liberdade da imprensa, foi promulgada quando se discutia o primeiro projeto do Código Criminal brasileiro, pois os legisladores entendiam que esse assunto deveria ser regulado por uma lei específica. Entretanto, mudaram de opinião e o projeto que se tornou o Código definitivo, em 16 de dezembro do mesmo ano da publicação da Lei supracitada, legislou a respeito do abuso de imprensa como delito e o incorporou, alterando as penalidades da Lei de 20 de setembro de 1830.

Os magistrados do STJ ainda acrescentaram em sua decisão que, em 1832, quando o artigo 12, $\S 7^{0}$ do Código do Processo Criminal estabeleceu que seria de alçada dos juízes de paz o julgamento dos crimes que tivessem como pena imposta a prisão de até seis meses, com multa correspondente à metade deste tempo, ou sem ela, tornou incompatível nesta parte a Lei.

É bom lembrar que muitas das penas aplicadas pela Lei especial eram compatíveis com o limite estabelecido para julgamento do juiz de paz. A Lei de setembro de 1830 atribuía ao Júri, composto de juízes eleitos por um procedimento próprio, o julgamento dos delitos por ela regulados.

Continuava o texto da decisão do STJ do ano de 1877 (TINOCO, 2003) afirmando que não havia dispositivo no Código do Processo Criminal excepcionando o caso das regras estabelecidas pela Lei de 20 de setembro de 1830, e mantendo os procedimentos daquela Lei. Mais um motivo para crerem que ela estaria revogada e excluída do sistema penal. Citou inclusive o artigo 324 do mesmo Código como exemplo. Como o legislador tinha a intenção de manter o foro diferenciado para os

${ }^{16}$ No seu Código Criminal Annotado, Tinoco (2003) inseriu o que chamava de "jurisprudência" do Supremo Tribunal de Justiça", manifestada em recurso de Revista (Rev. Crim. № 2274), por acórdão de 7 de março de 1877 e cita o acórdão de 1848, oriundo da província de Pernambuco. 
crimes de responsabilidade dos ministros de estado e conselheiros de estado, que continuariam a ser julgados pelo Supremo Tribunal de Justiça, assim como o foro militar, em causas meramente militares, e o foro eclesiástico, em causas meramente espirituais, deixou isso explícito em um artigo.

Ainda dizia a decisão do STJ que, se a Lei de 20 de setembro de 1830 não estivesse revogada, todos os processos relacionados aos delitos relacionados ao abuso de imprensa, que foram julgados pelo Júri comum, conforme o Código do Processo Criminal de 1832 e não pelos juízes eleitos de acordo com as regras da Lei de 20 de setembro de 1830, estariam nulos, o que não se sustentava. (TINOCO, 2003).

Lembraram que os juízes de paz, responsáveis pelo julgamento de pequenos delitos, não poderiam ser suspeitos somente quanto ao julgamento de crimes de abuso de imprensa. Isso não se coadunaria com um regime instituído por um Código do Processo Criminal que chamaram de "liberal".

Terminou sua decisão a turma do STJ afirmando que a prática constante quanto aos casos de julgamento dos crimes de abuso de imprensa sempre foi considerando a revogação da Lei de 20 de setembro de 1830, antes e depois do Acórdão do Supremo Tribunal de 22 de agosto de 1848, como declarava o Aviso de 15 de janeiro de 1851 (BRASIL, 1851), expedido sobre resolução de consulta do Conselho de Estado. (TINOCO, 2003).

Observou-se que o acórdão resultado de resposta a um recurso de revista oriundo da província de Pernambuco foi usado como paradigma por algum tempo, conforme texto do acórdão de 1877 apresentado (ALMEIDA, 1885) ${ }^{17}$. Na verdade, a turma de 1877 de magistrados do Supremo discordavam do entendimento da outra turma de vinte e nove anos atrás. A decisão de 1848, que foi por maioria de votos, versava sobre o crime de injúria, cometida por abuso de liberdade de imprensa, em periódico. Por meio dela, os magistrados daquela turma entendiam que competia ao Tribunal dos Jurados, em virtude da Lei de 20 de setembro de 1830, resolvida nesta parte pela Lei de 26 de outubro de 1831 (BRASIL, 1831), artigo 5ำ, e não ao chefe de polícia o seu julgamento final.

Alegavam que poderia até parecer que Lei de 3 de dezembro de 1841 (BRASIL, 1841), artigo $4^{\circ}, \S^{1^{\circ}}$, e o seu respectivo Regulamento $\mathrm{n}^{\circ} 120$ de 1842

17 1848. Aresto XXII. O julgamento de crime de liberdade de imprensa regula-se por legislação especial (Lei de 20 de setembro de 1830). Sentença de revista crime, entre partes, recorrente Luiz Antônio de Seixas, recorrido Antônio da Silva Castro. 
(BRASIL, 1842a), Seção 2ำ, artigo 3ำ §4ํㅡㄴ haviam sancionado o contrário. Todavia, como esta lei nada mais fez que transferir para os chefes de polícia a jurisdição conferida aos juízes de paz, pelo $\S 7^{\circ}$, art.12 do Código do Processo Criminal, para julgar crimes a que correspondem pequenas penas, seria manifesto que nessa generalidade de crimes não estava compreendido o delito de abuso de liberdade de imprensa, por menor que fosse a pena correspondente.

Explicavam esse entendimento por serem os crimes de abuso de imprensa regidos por uma lei especial que, segundo os princípios de Direito, nunca se entenderia alterada por Lei posterior, senão quando dito expressamente ou quando se tornasse com ela incompatível, segundo o Decreto de 6 de julho de 1693 (PORTUGAL, 1859). Ao final, mandaram remeter os autos à Relação de Pernambuco para revisão e novo julgamento. (TINOCO, 2003).

Interessante comentar a conclusão de Assis (2010, p. 66) quanto ao rigor da legislação relacionada à injúria. Diz a autora que, na prática da Justiça do Império do Brasil e "apesar do legislador empenhado, os injuriados precisaram bem mais do que de juízes, advogados e tribunais para reabilitar suas honras ofendidas". A Lei permitia que as honras dos ofendidos fossem reconhecidas de público, por meio da imprensa, de preferência, por intermédio de testemunhos e empenho de terceiros.

Para compreender melhor como eram julgados os réus incursos nos crimes de calúnia e injúria pela Relação pernambucana, faz-se necessário narrar pelo menos um dos casos nesta seção. Em um dos processos examinados neste trabalho, que teve recurso interposto em 1832 para a Relação de Pernambuco, foram acusados três réus, entre eles, dois capitães e um coronel ${ }^{18}$. Todos foram absolvidos das penas do artigo 13 da Lei de 20 de setembro de 1830. A conduta apontada como criminosa era a de fazer acusações por carta, dizendo que os requerentes iriam mandar 40 (quarenta) homens para Alagoa Nova, Paraíba, como uma afronta ao governo local. O queixoso recorreu, e a Relação de Pernambuco julgou o processo nulo por desrespeito às fórmulas da Lei de 20 de setembro de 1830, especificamente na formação do Conselho de Jurados. Ressalte-se que, nessa situação, como a decisão foi anterior à publicação do Código do Processo Criminal, o procedimento válido ainda seria aquele da Lei especial, pois somente mudaria depois da vigência do Código do Processo supracitado.

18 Fonte IAHGP. Tribunal da Relação de Pernambuco. Apelação. Apelante: José Domingues Monte Negro e seu irmão. Apelado: Francisco José Dias Bolcão e outros. 1832. Cx. 2. 
Os outros dois processos constantes do acervo analisado que tratavam sobre os delitos de calúnia e injúria, também acabaram por deixar os réus em liberdade. Um deles foi absolvido logo na primeira instância ${ }^{19}$. O outro, foi condenado no primeiro grau e o julgamento da primeira instância foi considerado nulo pelo Tribunal, por não ter se dado inteiro cumprimento do art. 209 do Código do Processo Criminal de 1832, sendo interposta revista ao STJ20.

Para efeito de comparação, apresenta-se a pesquisa de Assis (2010, p. 66), relacionada às comarcas de Cachoeira, Santo Amaro da Purificação e Salvador, na Bahia. Ela buscou notícias sobre os crimes de calúnia e injúria, ao longo do século XIX, nos jornais da época. Concluiu que a absolvição era constante para os "poucos" crimes de calúnia e injúria noticiados, mas assinala que "o Código Criminal do Império previa punições mais severas quando as calúnias e injúrias eram dirigidas ao Imperador e aos 'empregados da Nação' de mais alto coturno".

Importante ressaltar que todos os acusados por crimes de calúnia e injúria, se fosse na forma escrita, teriam que saber ler e escrever, privilégio de poucos no período imperial. Normalmente pessoas do sexo masculino, livres, cidadãos e eleitores, pertencentes à elite da sociedade.

Foi o caso dos cinco réus dos três processos que chegaram à Relação de Pernambuco de 1831 a 1850, analisados nesta pesquisa.

\section{CONSIDERAÇÕES FINAIS}

Este trabalho se propôs a contribuir para o entendimento acerca do funcionamento da Justiça criminal em Pernambuco de 1831 a 1850, período em que se iniciava a construção de um Direito Penal próprio no Brasil e de uma estrutura judicial que fosse capaz de realizar a prestação jurisdicional, conforme os parâmetros da época. Trouxe também como objetivo elucidar quem eram os acusados pela Justiça Criminal na província, especialmente em relação aos crimes contra a segurança da honra.

A partir da análise dos processos criminais e a comparação com as normas jurídicas do período imperial, constatou-se, conforme entendimento já consagrado no

\footnotetext{
${ }^{19}$ Fonte IAHGP. Tribunal da Relação de Pernambuco. Apelação. Apelante: Joaquim Inocêncio Gomes. Apelado: Manoel Joaquim Carneiro Leal. 1845. Cx. 2.

${ }^{20}$ Fonte IAHGP. Tribunal da Relação de Pernambuco. Apelação. Apelante: Antônio Joaquim de Mello. Apelado: o Juízo. 1838. Cx. 2.
} 
Direito, que a prática jurídica e a realidade social influenciaram na corporificação das normas, realizada a observação do que estava estabelecido na legislação e o que era cumprido pela Justiça.

Quanto aos procedimentos internos, melhor explicando, às formalidades escritas exigidas pelas normas para o bom andamento dos processos criminais, relacionadas à ordem e ao tipo de ato processual, elas eram, na maioria das vezes, respeitadas e seguidas pelos escrivães e magistrados, com a vigência do Código do Processo Criminal de 1832 (BRASIL, 1842b) e do Regulamento das Relações de 1833. (BRASIL, 1873).

Pode-se perceber claramente, ao observar o andamento do processo, como a política local influenciava a Justiça. Isso fica mais claro quando se constata quem eram as pessoas que julgavam no Judiciário pernambucano. Elas pertenciam às camadas sociais das elites locais. Tinham que saber ler e escrever, bem como para vários ofícios se exigia a formação em Direito. Mas esse currículo não era suficiente para ocupar o cargo. Para ser magistrado também se fazia necessário ter ligações sociais com as elites locais, inclusive para ser eleito como juiz de paz.

Quando foi feita a leitura do conteúdo dos processos pôde-se visualizar alguns detalhes da vida cotidiana da sociedade escravista em Pernambuco. Vellasco (2007) afirma que, em Minhas Gerais de 1831 até meados do Oitocentos, a Polícia se ocupava com os escravos e libertos e a Justiça intermediava conflitos entre os homens livres, embora que não exclusivamente. Para as comarcas de Pernambuco, no mesmo período, pode-se afirmar, quanto à Justiça criminal, que todas as demandas que foram encaminhadas à Relação, relacionadas aos crimes contra a segurança da honra, ocorreram entre homens livres.

Para os crimes contra a segurança da honra, constatou-se que, em Pernambuco, somente foram encaminhados à Relação casos em que os homens eram livres. Metade dos réus acusados do crime de estupro eram das elites locais. 0 acusado de ter praticado rapto era das camadas médias. Quanto ao delito de calúnia e injúria, todos pertenciam à camada das elites locais. Dessa maneira, pode-se considerar que, para esses tipos de crime, a maior parte dos casos que foram levados para serem revistos pelo Tribunal tinham como acusados pessoas das elites locais, conforme informações apresentadas neste artigo. 


\section{REFERÊNCIAS}

ALMEIDA, Cândido Mendes de. Arestos do STJ. Rio de Janeiro: B. L. Garnier, 1885.

ASSIS, Nancy Rita Sento Sé de. Tribunas de honra, Tribunais de Justiça: opinião pública e a moralidade Oitocentista. Passagens. Revista Internacional de História Política e Cultura Jurídica, Rio de Janeiro, v. 2, n. 5, p. 55-68, 2010. Disponível em: http://www.historia.uff.br/revistapassagens/artigos/v2n5a32010.pdf. Acesso em: 18 set. 2018.

BEVILÁQUA, Clóvis. Criminologia e direito. Bahia: Litho-typographia e encadernação, 1896.

BRASIL. Alvará de 15 de janeiro de 1810. Crêa a Comarca do Sertão de Pernambuco, e ergie em villas as Povoações de Pilão Arcado e de Flores Ribeira de Pajelrú. Rio de Janeiro, RJ: Império do Brasil, 1810. Disponível em:

http://bd.camara.gov.br/bd/bitstream/handle/bdcamara/18325/colleccao_leis_1810_p arte1.pdf. Acesso em: 24 jul. 2020.

BRASIL. Alvará de 22 de abril de 1808. Crêa o Tribunal da Mesa do Desembargo do Paço e da Consciencia e Ordens. Rio de Janeiro, RJ: Império do Brasil, 1808. Disponível em: http://www.planalto.gov.br/ccivil_03/Atos/alv/1808/alv-22-4-1808.html. Acesso em: 24 jul. 2020.

BRASIL. Aviso de 15 de Janeiro de 1851. Declara que nenhuma província se torna necessária acerca das terras habitadas pelos Índios da Povoação de S. Benedito, na província do Ceará. Rio de Janeiro: Ministério dos Negócios do Império, 1851.

Disponível em:

https://bd.camara.leg.br/bd/bitstream/handle/bdcamara/18381/colleccao_leis_1851_p arte3.pdf?sequence=3\&isAllowed=y. Acesso em: 24 jul. 2020.

BRASIL. Aviso no 190 de 17 de julho de 1852. Ao Presidente da Província de São Paulo. - Declara que as disposições do Art. $10 \times 1^{\circ}$ do Código Criminal, são também aplicáveis aos escravos menores. Rio de Janeiro: Ministério dos Negócios da Justiça, 1852. Disponível em:

http://www.ciespi.org.br/media/Base\%20Legis/AVISO\%20190_17_JUL_1852.pdf. Acesso em: 24 jul. 2020.

BRASIL. Codigo de processo criminal de primeira instancia para o Imperio do Brasil, com notas, nas quaes se mostrão os artigos que forão revogados, ampliados ou alterados, seguido da disposição provisoria acerca da administração da justiça civil e da lei de 3 de dezembro de 1841 que reforma 0 mesmo código. Rio de Janeiro: Typographia de Manoel José Cardoso, 1842b. Disponível em: https://www2.senado.leg.br/bdsf/handle/id/220538. Acesso em: 31 ago. 2020.

BRASIL. Collecção das Leis do Império do Brasil: parte segunda. Rio de Janeiro: Typographia Nacional, 1873. Disponível em: https://bd.camara.leg.br/bd/bitstream/handle/bdcamara/18463/colleccao_leis_1833_p arte2. pdf?sequence=2\&isAllowed=y. Acesso em: 31 ago. 2020. 
BRASIL. [Constituição de (1824)]. Constituição Política do Império do Brasil, elaborada por um Conselho de Estado e outorgada pelo Imperador D. Pedro I, em 25.03.1824. Rio de Janeiro: Coleção de Leis do Império do Brasil, 1824. Disponível em: https://www2.camara.leg.br/legin/fed/consti/1824-1899/constituicao-35041-25marco-1824-532540-publicacaooriginal-14770-pl.html. Acesso em: 24 jul. 2020.

BRASIL. Decreto de 18 de junho de 1822. Crêa Juizes de Facto para julgamento dos crimes de abusos de liberdade de imprensa. Rio de Janeiro, RJ: Presidência da República, 1822. Disponível em:

http://www.planalto.gov.br/ccivil_03/decreto/historicos/dim/DIM-18-6-1822-2.htm. Acesso em: 24 jul. 2020.

BRASIL. Decreto de 3 de janeiro de 1833. Dá Regulamento para as Relações do Império. Rio de Janeiro, RJ: Império do Brasil, 1833. Disponível em: https://bd.camara.leg.br/bd/bitstream/handle/bdcamara/18463/colleccao_leis_1833_p arte2.pdf? sequence=2\&isAllowed=y. Acesso em: 24 jul. 2020 .

BRASIL. Decreto de 9 de novembro de 1830. Determina o modo porque nas Relações devem ser distribuídas, relatadas e julgadas as appelações dos Juntas de Justiça e as revistas civeis e criminaes. Rio de Janeiro: Império do Brasil, 1830c. Disponível em:

http://www.camara.leg.br/Internet/InfDoc/conteudo/colecoes/Legislacao/leisocerizada s/Leis1830vlLeg.pdf. Acesso em: 24 out. 2018.

BRASIL. Lei de 16 de dezembro de 1830. Manda executar o Codigo Criminal. Rio de Janeiro: Secretaria de Estado dos Negocios da Justiça, 1830a. Disponível em: http://www.planalto.gov.br/ccivil_03/leis/lim/lim-16-12-1830.htm. Acesso em: 24 jul. 2020.

BRASIL. Lei de 18 de setembro de 1828. Crêa o Supremo Tribunal de Justiça e declara suas attribuições. Rio de Janeiro: Coleção de Leis do Império do Brasil, 1828a. Disponível em: https://www2.camara.leg.br/legin/fed/lei_sn/1824-1899/lei38214-18-setembro-1828-566202-norma-pl.html. Acesso em: 24 jul. 2020.

BRASIL. Lei de 20 de setembro de 1830. Sobre o abuso da liberdade da imprensa. Rio de Janeiro: Império do Brasil, 1830b. Disponível em:

https://www2.camara.leg.br/legin/fed/lei_sn/1824-1899/lei-37987-20-setembro-1830565654-publicacaooriginal-89402-pl.html. Acesso em: 24 jul. 2020.

BRASIL. Lei de 23 de setembro de 1828. Prescreve as formalidades que se devem observar nos processos criminaes, e a maneira por que devem ser instruidos e preparados os que forem julgados nas Juntas de Justiça. Rio de Janeiro: Império do Brasil, 1828b. Disponível em: https://www2.camara.leg.br/legin/fed/lei_sn/18241899/lei-38220-23-setembro-1828-566246-publicacaooriginal-89873-pl.html. Acesso em: 24 jul. 2020.

BRASIL. Lei de 26 de outubro de 1831. Prescreve o modo de processar os crimes publicos e particulares e dá outras providencias quanto aos policiaes. Rio de Janeiro: Império do Brasil, 1831. Disponível em: 
https://www2.camara.leg.br/legin/fed/lei_sn/1824-1899/lei-37623-26-outubro-1831564670-norma-pl.html. Acesso em: 24 jul. 2020.

BRASIL. Lei de 29 de novembro de 1832. Promulga o Codigo do Processo Criminal de primeira instancia com disposição provisoria ácerca da administração da Justiça Civil. Rio de Janeiro, RJ: Presidência da República, 1832. Disponível em: http://www.planalto.gov.br/ccivil_03/leis/lim/LIM-29-11-1832.htm. Acesso em: 24 jul. 2020.

BRASIL. Lei no $\mathbf{1 1 . 1 0 6}$ de 28 de março de 2005. Altera os arts. 148, 215, 216, 226, 227, 231 e acrescenta o art. 231-A ao Decreto-Lei no 2.848, de 7 de dezembro de 1940 - Código Penal e dá outras providências. Brasília, DF: Presidência da República, 2005. Disponível em: http://www.planalto.gov.br/ccivil_03/_Ato20042006/2005/Lei/L11106.htm. Acesso em: 24 jul. 2020.

BRASIL. Lei no 261, de 3 de dezembro de 1841. Reformando o Codigo do Processo Criminal. Rio de Janeiro: Império do Brasil, 1841. Disponível em: http://www.planalto.gov.br/ccivil_03/leis/lim/LIM261.htm. Acesso em: 24 jul. 2020.

BRASIL. Lei no $\mathbf{4}$ de $\mathbf{1 0}$ de junho de 1835. Determina as penas com que devem ser punidos os escravos, que matarem, ferirem ou commetterem outra qualquer offensa physica contra seus senhores, etc.; e estabelece regras para o processo. Rio de Janeiro: Império do Brasil, 1835. Disponível em:

http://legis.senado.leg.br/norma/540816/publicacao/15632879. Acesso em: 24 jul. 2020.

BRASIL. Regulamento no 120, de 31 de janeiro de 1842. Regula a execução da parte policial e criminal da Lei no 261 de 3 de Dezembro de 1841. Rio de Janeiro: Império do Brasil, 1842a. Disponível em:

http://www.planalto.gov.br/ccivil_03/Regulamentos/R120.htm. Acesso em: 24 jul. 2020.

DORLHNIKOFF, Miriam. História do Brasil Império. São Paulo: Contexto, 2017.

DUBY, George. Le chevalier, la femme et le prêtre: le marriage da France féodale. Paris: Hachette, 1981.

FREUD, Sigmund. The standard edition of the complete psychological works. Londres: Hoarth Press, 1968.

GAMA, Jozé Bernardo Fernandes. Memórias históricas da província de Pernambuco, precedidas de um ensaio topográfico-histórico. Tomo I. Pernambuco: Typographia de M. P. de Faria, 1848.

LYRA, Roberto. Introdução ao estudo do direito penal. Rio de Janeiro: Editora Nacional de Direito, 1946.

MAQUIAVEL, Nicolau. Discursos sobre a primeira década de Tito Lívio. Brasília, DF: UnB, 1982. 
MATTOSO, Katia M. de Queirós. Bahia, século XIX: uma província no império. Rio de Janeiro: Nova Fronteira, 1992.

MATTOSO, Katia M. de Queirós. Sociedade e conjuntura na Bahia nos anos de luta pela Independência. Universitas, n. 15/16, p. 5-26, 1973.

MELLO, Jeronymo Martiniano Figueira de. Ensaio sobre a estatística civil e política da Província de Pernambuco. Recife: Conselho Estadual de CulturaEstado de Pernambuco, 1979.

MOURA FILHO, Heitor Pinto de. Um século de pernambucanos mal contados: estatísticas demográficas nos oitocentos. 2005. Dissertação (Mestrado em História Social) - Instituto de Filosofia e Ciências Sociais, Universidade Federal do Rio de Janeiro, Rio de Janeiro, 2005.

PORTUGAL. Collecção chronológica da legislação portugueza compilada e annotada por José Justino de Andrade e Silva. Lisboa: Imprensa Nacional, 1859. Disponível em: http://www.governodosoutros.ics.ul.pt/?menu=consulta\&id_partes=103\&id_normas=2 9118\&accao=ver\&pagina=352. Acesso em: 24 jul. 2020.

TINOCO, Antônio Juiz Ferreira. Código criminal do Império do Brazil annotado. Brasília, DF: Senado Federal, Conselho Editorial, 2003. Disponível em: http://www2.senado.leg.br/bdst/item/id/496203. Acesso em: 18 set. 2018.

TOMASELLI, Sylvana; PORTER, Roy. Estupro. Tradução: Alves Calado. Rio de Janeiro: Rio Fundo, 1992.

TOMASELLI, Sylvana. PORTER, Roy. Rape: an historical and cultural enquiry. Oxford, Basil Blackwell, 1989.

VELLASCO, Ivan. Policiais, pedestres e inspetores de quarteirão: algumas questões sobre as vicissitudes do policiamento na província de Minas Gerais (1831-1850). In: CARVALHO, José Murilo (org.). Nação, cidadania no Império: novos horizontes. Rio de Janeiro: Civilização Brasileira, 2007. p. 237-266.

VELLASCO, Ivan. As seduções da ordem: violência, criminalidade e administração da justiça: Minas Gerais - século 19. São Paulo: EdUSC, 2004.

WEHLING, Arno. Administração portuguesa no Brasil de Pombal a D. João (1777-1808). Brasília, DF: Fundação Centro de Formação do Servidor Público, 1986. 